ACTA MYCOLOGICA

Vol. 41 (1): 11-20

2006
Dedicated to Professor Alina Skirgietto

on the occasion of her ninety fifth birthday

\title{
Hymenoscyphus subcarneus, a little known bryicolous discomycete found in the Białowieża National Park
}

\author{
HANS OTTO BARAL ${ }^{1}$ and LOTHAR KRIEGLSTEINER ${ }^{2}$
}

${ }^{1}$ Blaihofstr. 42, D 72074 Tübingen

${ }^{2}$ Konrad Adenauer Str. 32, D 73529 Schwäbisch Gmünd

Baral H. O., Krieglsteiner L.: Hymenoscyphus subcarneus, a little known bryicolous discomycete found in the Białowieża National Park. Acta Mycol. 41 (1): 11 20, 2006.

The discomycete Hymenoscyphus subcarneus was found to grow parasitic on the liverwort Cephalozia catenulata in the Białowieża National Park (Poland), and is described and illustrated from the fresh collection. Two characters, the ascus apical ring structure of the Calycina type and the contents of the living paraphyses (multiguttulate by low refractive vacuolar bodies), have not been reported previously. In addition, a dried collection on Pohlia gracilis from Switzerland, Grimsel area, was studied. The relationship, taxonomy and infraspecific variation of the fungus are discussed. A new genus, Roseodiscus, is established to accomodate this bryicolous fungus together with two very similar equiseticolous species, Hymenoscyphus rhodoleucus and $H$. equisetinus. The three species are macroscopically characterized in the fresh state by a pale rosaceous lilaceous hymenium and a mostly slender, concolorous or whitish stipe. Roseodiscus resembles Hymenoscyphus in various respects, but sharply deviates in the apical ring type which appears to indicate a more close relationship with genera like Calycina or Stamnaria. Rhizoscyphus ericae which forms a mycorrhiza with roots of Ericaceae, is compared with Roseodiscus. Based on vital observations of $R$. ericae this species is believed to be congeneric with the type of Pezoloma, P. griseum.

Key words: Roseodiscus, Rhizoscyphus ericae, Hymenoscyphus rhodoleucus, bryicolous

\section{INTRODUCTION}

In June, 1996, the second author and Angelika Huber, the latter working on bryophytes, had the opportunity to collect in the nature reserve of Białowieża National Park. The visit in Poland came about by an exchange between the universities of Regensburg and Lódź. An interesting discomycete could be found that is described and illustrated here. 


\section{DESCRIPTION OF SPECIES}

Hymenoscyphus subcarneus (Sacc.) O. Kuntze, Rev. Gen. Pl. 3 (2): 486 (1889) nom. illeg. [non Hymenoscyphus subcarneus (Schumach.) J. Schröt., Schles. Kryptfl. 3.2: 69 (1893) $\equiv$ Phaeohelotium subcarneum (Schumach.) Dennis, Kew Bull. 25: 355 (1971)]

[ $\equiv$ Peziza subcarnea Cooke and Peck in Cooke, Bull. Buffalo Soc. Nat. Sci. 2: 295 (1875), nom. illegit.; non Peziza subcarnea Schumach., Flora danica 12, tab. 2084, fig. $1(1832)]$

$\equiv$ Phialea subcarnea Sacc., Syll. Fung. 8: 265 (1889)

三Helotium destructor Peck in White, Mycologia 34: 163 (1942) [nom. nov., non Helotium subcarneum (Schumach.) Sacc., Michelia 2(7): 260 (1881)]

Description of the sample from Poland (* living state)

Apothecia scattered to subgregarious, fresh (0.4-)0.5-1.3(-1.5) mm, shallowly cup- to saucer-shaped, whitish but with a distinct pale pink tint, stalk 0.6-1.2 x 0.2$0.35 \mathrm{~mm}$, abruptly delimited from cup, concolorous, pale ochraceous towards base, exterior nearly smooth under a hand lens, at higher magnification delicately pubescent, especially near margin, margin of large apothecia often undulating to somewhat irregular. Ectal excipulum of a horizontally $\left(10-20^{\circ}\right)$ oriented hyaline textura prismatica of thin-walled cells, individual cells *(12-)20-45(-67) x (6-)10-13(-16) $\mu \mathrm{m}$ in both surface view and median section, externally covered by a loose network of 3-5 $\mu \mathrm{m}$ wide eguttulate hyphae, towards margin of t. porrecta oriented at c. $10^{\circ}$, cells (in $\mathrm{KOH}$ ) 13-18 x 2.5-4 $\mu \mathrm{m}$, not differentiated from covering hyphae which terminate here in somewhat projecting hair-like ends that contain in the living state low-refractive guttules (VBs), in stalk of t. porrecta. No crystals and no amyloid or dextrinoid tissue observed. Medullary excipulum near ectal excipulum of a broad textura porrecta, in centre of a small region of dense t. intricata (individual cells here in $\mathrm{KOH}$ 12-25 x 3-4 $\mu \mathrm{m})$. Asci *52-66 x 6.5-7.5(-10) $\mu \mathrm{m}$, in $\mathrm{KOH} 42-57$ x (5.5-)6-7(-7.5) $\mu \mathrm{m}$, pars sporifera *(15-)20-26 $\mu \mathrm{m}$ long, 8-spored, apex strongly conical, apical ring deep blue in IKI (type BB euamyloid), of the Calycina-type, 0.6-1 $\mu \mathrm{m}$ high and 0.9-1.1 $\mu \mathrm{m}$ wide (dead state), base attenuated or rather broad, arising from croziers. Spores biseriate within the living asci, free *(5.2-)6-8.5(-10) x (1.8-)2-2.6(-3) $\mu \mathrm{m}$, in $\mathrm{KOH}$ c. $6-8 \times 2-2.3 \mu \mathrm{m}$, of variable length, slightly to mainly strongly clavate or pyriform or even somewhat cuneate (triangular), hyaline, smooth, with a few very minute LBs in each spore half, no surrounding sheath observed. Paraphyses cylindrical to slightly clavate, even in dead state 3-7 $\mu \mathrm{m}$ shorter than the asci, terminal cell *(11-)16-37 x 2.8-3.5(-4) $\mu \mathrm{m}$, in living state multiguttulate in the upper $25-40 \mu \mathrm{m}$ by globose, low (to medium) refractive VBs (large drops sometimes strongly elongated), VBs disappearing in $\mathrm{KOH}$, invisible in dead cells.

ExAmined COllection: Poland, Białowieża National Park, ca. $1 \mathrm{~km}$ north of administration centre Białowieża, ca. $130 \mathrm{~m}$ a.s.l., parasitic on living, green gametophytes of Cephalozia catenulata (Hüb.) Lindb. growing on a log of Picea abies lying on the ground on wayside, 28.VI.1996, L. Krieglsteiner and A. Huber (Figs 1-2; 3).

Specimen deposited in the herbarium Krieglsteiner (Stuttgart) and private herbarium H.-O. Baral (H.B. 5531). 
Further collection studied: Switzerland, Bern, Grimsel-Guttannen area, Bächlisboden, Sander, $2170 \mathrm{~m}$ a.s.l., over granite, parasitic on Pohlia gracilis, 26.VIII.1986, B. Senn-Irlet, B.I. 86/88, H.B. 3341.

\section{REPORTS OF HYMENOSCYPHUS SUBCARNEUS IN THE LITERATURE}

Ade (1935: 24) reported under the name Phialea subcarnea two collections from Austria (Tirol, Vennatal and Roßkogel above Inzingeralpen, summer 1925 and 1927). His description fits more or less to ours, except that he states the spores to be "elongate, often slightly curved, with narrow, bright mucilaginous sheath". The "sheath" might be a mistake for dead spores with detached plasma, perhaps observed from within the asci. Ade gave the spore size as "6-7 x 2-5" $\mu \mathrm{m}$, but in view of the indicated ascus size $(40-50 \times 5-6 \mu \mathrm{m})$ and the irregularly biseriate spore arrangement, Ade's spore width is probably an error for $2-2.5 \mu \mathrm{m}$. The rather narrow excipular cells ("upto $18.5 \times 3.5 \mu \mathrm{m}$ ") forming a t. porrecta might be due to the immature collection.

White (1942, as Helotium desctructor) examined much over a dozen of collections from U.S.A. (New York, Michigan) and Canada (Alberta, New Hampshire, Ontario) including the type specimen (U.S.A., New York, Indian Lake, on Jungermannia sp., C. H. Peck 319). The apothecia are distinctly smaller than in our collection: $0.2-0.4(-0.5) \mathrm{mm}$ diam., total height upto $1 \mathrm{~mm}$, "scarcely visible to the unaided eye" (possibly measured in the dry state). Ascus (40-50 x 5-6 $\mu \mathrm{m})$ and spore size (4.5$6 \times 2-2.5 \mu \mathrm{m})$ are a bit smaller than in our collection when comparing the dead state. The pyriform spore shape as well as the conical ascus apex and presence of croziers as depicted by White perfectly fit to our collection.

Den $\mathrm{n}$ is (1964: 68, as Hymenoscyphus subcarneus) studied the excipular characters from the type. In concordance with our fungus, Dennis reported the cells to be rather broad, "about 20-30 x $10 \mu \mathrm{m}$, lying at a very low angle to the surface".

With little doubt, Lizoñ (1992: 48) described under the name H. subcarneus the same species. The material studied by him was collected in Slovakia (Belanské Tatry, in valle Holubyho dolina pr. Tatranská Kotlina, 10.VIII.1956, M. Svrček, PRM $817510)$. Both the ascus width $(40.5-60 \times 5-6 \mu \mathrm{m})$ and the spore length (4.5-6 x 2-2.5 $\mu \mathrm{m})$ given by Lizoň (gained from dead herbarium material), appear to have partly been copied from White, since Lizoň stated that he could examine "only young, not fully mature fruit-bodies".

Triebel (1999: 10) reported a recent collection from Canada (ca. $75 \mathrm{~km} \mathrm{NNE}$ of Québec, Forêt Montmorency). The fungus was identified by P. Döbbeler and said to grow on at least five different bryophytes. Except for the apothecial colour (distinctly pink) no further comments were published.

The here studied collection from Switzerland (on Pohlia gracilis) differs from all the above in distinctly longer asci (80-100 x 6-9 $\mu \mathrm{m}$, living state) and ascospores (ellipsoid-oblong, *8.5-13.5 x 2.7-3.2 $\mu \mathrm{m})$. The question whether or not this represents a separate species must await further field work. Similar variability was observed by us in Hymenoscyphus rhodoleucus (Fr.: Fr.) W. Phillips and H. equisetinus (Velen.) Dennis, two species which are obviously closely related to $H$. subcarneus (see below). Due to a rather high variation in spore size, the delimitation between these two equiseticolous taxa is still not fully settled. 


\section{HOMONYMY WITH PEZIZA SUBCARNEA SCHUMACH.}

A somewhat similar species with a similar name, Phaeohelotium subcarneum (Schumach.) Dennis, has also pinkish apothecia but lacks a stalk and was mainly reported from bark and wood. It was redescribed by Höhnel (1926: 99), Grelet (1948: 108), Dennis (1971: 355), Breitenbach \& Kränzlin (1981, pl. 173), and Baral (1986: 17) from non-authentic material. The species was even combined in Hymenoscyphus Gray as H. subcarneus (Schumach.) J. Schröt., four years after O. Kuntze transferred Peziza subcarnea Cooke and Peck to that genus. De n n is (1971) is obviously in error when citing the species as Phaeohelotium subcarneum (Schumach. ex Sacc.) Dennis, because Peziza subcarnea Cooke and Peck is illegitimate, not the earlier Peziza subcarnea Schumach.

The few known reports of Phaeohelotium subcarneum are possibly not homogeneous, at least the brief descriptions support such a conclusion. That $P$. subcarneum is a synonym of Hymenoscyphus imberbis (Bull.: Fr.) Dennis was erroneously cited by Verkley (1995: 180). In fact, Baral (Baral \& Krieglsteiner 1985: 129) stated that $P$. subcarneum in the sense of Breitenbach and Kränzlin seems to belong to $H$. imberbis or a closely related species. P. subcarneum s. Ba ral (1986) has a Calycinatype of apical ring and is therefore unrelated to Hymenoscyphus (incl. Phaeohelotium Kanouse). The ectal excipulum of t. globulosa without a covering layer appears to separate it sharply at generic level from Hymenoscyphus subcarneus (Sacc.) O. Kuntze. Furthermore, the apothecia are fresh greyish-white and turn only pinkish with age or when dried. The generic position of this species remains unclear upto now.

\section{GENERIC POSITION OF HYMENOSCYPHUS SUBCARNEUS (SACC.) O. KUNTZE}

Dennis (1964: 43) and Lizoň (1992) believed that the bryicolous species is a normal Hymenoscyphus. However, the rather wide generic concepts of the two authors included in Hymenoscyphus also species of Calycina (Nees) Gray, due to the frequent neglection of apical ring types in light-microscopical studies. The apical ring of $H$. subcarneus is of the Calycina-type: rather thick in optical section, widest in its upper part which extends to the very apex, here most strongly reactive (B a r al 1987, fig. 26; Verkley 1995: figs. 4.74-76, 186, "type VIII: Chlorociboria-Pezizella-Calycina"), and the ascus apex is strongly conical. This type of ascus apex is very much unlike that of typical members of Hymenoscyphus with a truncate, broadly conical apex and a narrow ring that is usually only present in the lower half of the apical thickening as two very thin amyloid lines which are not widened apically (Baral 1987, figs 10-12). The guttulate paraphyses and the presence of a covering layer of narrow hyphae over the excipulum would, however, fit very well in that genus.

The genera Bryoscyphus Spooner and Muscicola (Velen.) Svrček likewise differ from our fungus in ascus structure (Hymenoscyphus-type; Baral \& Marson 2005), the latter also in the presence of distinct, strongly uncinate hairs.

Two taxa growing on stems of Equisetum, Hymenoscyphus rhodoleucus and $H$. equisetinus, strongly resemble our species in their pinkish apothecia, but also in their microscopical characters. Like $H$. subcarneus, both have apical rings of the Caly- 
cina-type (Baral \& Marson 2005) and are therefore clearly misplaced in the genus Hymenoscyphus. Svrček (1959) already compared one of the two (as Phialea rhodoleuca) with our species (as Phialea subcarnea). Placement of H. rhodoleucus in Phialea (Fr.) Gillet ( Cyathicula de Not.) was favoured by Nannfeldt (1932) while Dennis $(1956,1978)$ preferred to assign the two equiseticolous species to Hymenoscyphus.

Macroscopically, our bryicolous species indeed somewhat resembles a Cyathicula. However, members of that genus have a strongly gelatinized excipulum and often also crystals on the exterior, both absent in our species. The ascus structure varies strongly among the accepted species (Triebel \& Baral 1997 as Crocicreas Fr.), comprising both the Hymenoscyphus- and the Calycina-type. However, the latter occurs only in the type species of Crocicreas which should better be distinguished at the generic level. The guttulate paraphyses and the covering layer in our species would fit to Cyathicula.

Species of Calycina differ from our fungus in having a more gelatinized ectal excipulum of much shorter cells which often lie at a higher angle to the surface, and in constantly lacking an external covering hyphal layer. The hairs of Calycina emerge directly from the prismatic excipular cells. Furthermore, spores of Calycina are usually homopolar. Last but not least, the VBs in the living paraphyses of Calycina species are generally strongly elongate, not multiguttulate. The genus Calycina was transferred form the Helotiaceae to the Hyaloscyphaceae by the first author (B a r a 1 \& Krieglsteiner 1985).

The genus Stamnaria Fuckel is characterized by a gelatinized layer outside the ectal excipulum, and the presence of carotenoids in both excipulum and paraphyses. Otherwise it shows some similarities with our species, including the apical ring which is of the Calycina-type in S. equiseti (Hoffm.) Sacc. (Künkele et al. 2005).

The genus Rhizoscyphus W. Y. Zhuang and Korf was described in Zhang \& Zhuang (2004) to accomodate R. ericae (D. J. Read) W. Y. Zhuang and Korf (三 Hymenoscyphus ericae (D. J. Read) Korf and Kernan), a species with a mycorrhizal connection to roots of Ericaceae. The erection of a new genus was mainly based on molecular data, but also on the symbiontic relationship with the host plants. Huhtinen (Ha mblet on et al. 1999) redescribed the species in detail including vital characters. Following his report, the living paraphyses are without any refractive vacuoles and the apical ring is of the Calycina-type. Characteristic of the species is the hyphoid margin which gives the apothecia a hairy appearance, also the sometimes furcate apices of paraphyses and the simple-septate ascus bases with often a downward protuberance. Clearly, the apical ring excludes Hymenoscyphus s.str. The microscopical data are indeed similar to H. subcarneus, but the subsessile hairy apothecia more resemble a Hyaloscyphaceae.

Recently the first author had the opportunity to study a fresh specimen of $R$. ericae detected by P. Zinth. The apothecia were formed on the rootlets of a Rhododendron sp. that grows in an semi-sterilized artificial medium in a pot culture in his house in Egelsbach near Frankfurt (Hessen). The specimen fully matches Huhtinen's analysis. In addition, the mature living asci each contained one globose, refractive drop (4-4.5 $\mu \mathrm{m}$ diam.) below the pars sporifera similar as in the genus Psilachnum Höhn. These drops disappear in dead asci and were also seen in fresh finds of Pezoloma ciliifera (P. Karst.) Korf and P. marchantiae (Sommerf.) Benkert 
(Baral \& Marson 2005), two species which share some further characteristics of $R$. ericae like the subsessile apothecia, the type of apical ring and the eguttulate, sometimes apically furcate paraphyses. The two species differ in an external gel layer and in marginal teeth composed of narrow agglutinated hyphae. These teeth are a striking feature of the typical species of Pezoloma Clem., but are absent in many other taxa assigned to that genus. The hyphae of the teeth indeed resemble the hair-like protrusions of $R$. ericae. Similar differences between dentate and adentate apothecia are accepted within the genus Cyathicula. However, the genus Pezoloma in the current circumscription (e.g., Garcia \& Van Vooren 2005) is heterogenous and includes also taxa with a typical Hymenoscyphus-type of apical ring. The presence of an external gel layer which is used to define the genus is most probably a polyphyletic feature whereas differences in the apical ring type appear to have much more been conserved during evolution.

Based on the above data it seems wise to restrict the genus Pezoloma to species with a Calycina-type of apical ring. The morphology of $R$. ericae appears to be quite close to $P$. ciliifera and $P$. marchantiae. These in turn are surely very closely related to the type species of Pezoloma, P. griseum Clem., which has also a toothed margin. While the former two species are partly found growing on mosses (Sphagnum, Marchantia), P. griseum was reported by Cle ments (1911) to grow on rootlets of Betula, suggesting a mycorrhizal life style similar as in $R$. ericae. Moreover, $R$. ericae was two times isolated as endophytic mycelium in a liverwort (Cephaloziella, Chambers et al. 1999). It is therefore believed that the type species of Rhizoscyphus and Pezoloma belong to the same genus. Hence the following new combination is proposed. Molecular research on species of Pezoloma and a comparison with the sequence of $R$. ericae would highly be appreciated.

Pezoloma ericae (D. J. Read) Baral comb. nov.

Basionym: Pezizella ericae D. J. Read, Trans. Brit. Mycol. Soc. 63: 381 (1974)

The genus Moserella Pöder and Scheuer (1994), with the single species M. radicicola Pöder and Scheuer, was described as having very minute, strongly convex (capitate), white (to yellowish) apothecia with long and very slender stalks growing hypogeus on ectomycorrhizal rootlets of Picea abies. The ascus apex is very precisely illustrated, clearly showing the Calycina-type of apical ring. The microscopical features are not unlike our fungus, except for the spores which are said to be finely warted. Possibly Moserella is also closely related to Pezoloma.

There appears to exist no genus to which the three species with rose apothecia can safely be assigned. A new genus is therefore proposed.

Roseodiscus Baral gen. nov.

Speciis generis Hymenoscyphus sensu stricto similis sed asci apice valde conici, annulus apicalis typo Calycina, apothecia hymenio pallide roseo-lilacea, excipulum ectale textura prismatica, pars externa hyphis tecta. In Equisetis vel Bryophyta crescunt.

Apothecia 0.5-1.8 mm diam., disc flat, pale rose-lilaceous (salmon-coloured to carneous or pinkish), stipe whitish to concolorous, rather translucent, 0.25-2 x 0.2$0.6 \mathrm{~mm}$, base hyaline to faintly brownish, superficial or erumpent from beneath epidermis, whole exterior partly very finely pubescent. Ectal excipulum of large-celled, thin-walled, non-gelatinized textura prismatica oriented at a low angle $\left(10-20^{\circ}\right)$ to 
the surface, externally covered by a loose network of hyphae from which hair-like projections may emerge, towards margin of t. porrecta. Medullary excipulum nongelatinized, of dense t. intricata in centre, on flanks near ectal excipulum forming a broad t. porrecta. Asci 8-spored, with strongly conical apex with deeply amyloid $(\mathrm{BB}, \mathrm{rB})$ apical ring of Calycina-type, arising from croziers. Paraphyses *(2.5-)3$3.5(-4) \mu \mathrm{m}$ wide, containing either non-refractive vacuoles (species on Equisetum) or near apex multiguttulate by slightly (to medium) refractive vacuolar bodies (VBs). Ascospores cylindric-clavate to narrowly ellipsoid, partly slightly constricted in the middle, aseptate (rarely a few septate) when within the living asci, overmature often 1-septate, with a low lipid content, containing glycogen bodies.

In bogs and swamps, parasitic to saprotrophic on Bryophyta and Equisetum.

Typus generis: Roseodiscus rhodoleucus (Fr.: Fr.) Baral, comb. nov.

Basionym: Peziza rhodoleuca Fr., Obs. Mycol. II: 306 (1818)

$\equiv$ Hymenoscyphus rhodoleucus (Fr.: Fr.) W. Phillips, Brit. Discom. p. 131 (1887)

Further species included:

Roseodiscus equisetinus (Velen.) Baral, comb. nov.

Basionym: Septatium equisetinum Velen., Monogr. Discom. Bohem. p. 212 (1934)

三 Hymenoscyphus equisetinus (Velen.) Dennis, Brit. Ascom. p. 138 (1978)

Roseodiscus subcarneus (Sacc.) Baral, comb. nov.

Basionym: Phialea subcarnea Sacc., Syll. Fung. 8: 265 (1889)

Roseodiscus resembles the genus Hymenoscyphus by macroscopy, but sharply differs in the Calycina-type of amyloid apical ring (see above). In one collection of $R$. rhodoleucus an associated phialidic anamorph could be observed: broadly lageniform hyaline phialides $(* 10.5-17 \times 4-5.7 \mu \mathrm{m})$ with a narrow collarette produced cylindric-ellipsoid, basally truncate phialoconidia $(* 6.5-10 \times 1.6-3 \mu \mathrm{m})$. The same phialides were also sometimes seen emerging from the ectal excipulum.

The new genus is obviously more related to Stamnaria, Pezoloma and Calycina than to Hymenoscyphus. This is confirmed in the phylogenetic analysis of $\mathrm{Zhang}$ \& Zhuang (2004) where H. rhodoleucus is found far away from the main part of Hymenoscyphus, but clustering together with Calycina herbarum (Pers.) Gray (Hyaloscyphaceae), whereas Pezoloma ericae is found in a separate clade quite far away from these two.

\section{ECOLOGY AND PARASITISM}

R. subcarneus appears to be a montaneous to subalpine and probably also boreal species, at least in Europe. Ade's (1935) collections were reported to have grown in the alps between 1500 and $1800 \mathrm{~m}$ on north-exposed slopes, the one of Svrč ek (1959) in c. 1200 m. In North America the species was collected, e.g., in the Adirondack Mountains (eastern U.S.A.) and in Canada. White (1942) assumed that the species is not uncommon in that area. The N-American collections were made in (August-)September, except for Peck's type (July), while those from Europe were made during June-August.

The reported host plants are: Blepharostoma trichophyllum Dum. (Ade), Cephalozia catenulata (present study), Dicranum flagellare Hedw. (White, Ontario), Junger- 
mannia sp. (Peck's type, New York), "foliose hepatic" (Svrček, Lizoň), various bryophytes like Dicranum sp., Hypnum sp., Lepidozia reptans (L.) Dum., Polytrichum sp., Tetraphis pellucida Hedw. (Triebel). According to White, "there seem to be no morphological differences between the forms on liverworts and those on mosses". The mosses grew on old trunks (USA, Canada, Poland), or over stony ground ("Glimmerschiefer", Tirol).

$R$. subcarneus appears to be a parasitic species which has already been stated by Peck and H. S. Jackson (White 1942: 165), Ade (1935), and Svrček (1959). H. S. Jackson stated that "the apothecia are best located by first searching out the brown areas in green patches of mosses where the plants have evidently been killed by the fungus". Also Ade described a parasitic growth in his collections. The fungus is said to kill the tissue and thereby changes the colour of the moss population by forming circular yellow-brown lesions (Ade 1935). More or less distinct lesions could also be observed in our specimen from Poland.

Acknowledgements. We want to thank A. Bresinsky (D Regensburg) and M. Ławrynowicz (Łódź) for the possibility to drive to Poland, Angelika Huber (D München) for the company at the visit and the excursions as well as for the determination of Cephalozia catenulata. We are also much indebted in B. and G. Sumorok for the enormous logistic help. Thanks also to J. B. Faliński the director of Geobotanical Station (University of Warsaw) for the licence for collecting permission in the National Park. P. Döbbeler (D München) and C. Hahn (D Augsburg) contributed to the correct determination of the fungus by calling into our attention the paper of P. Lizoň. S. Huhtinen is thanked for valuable comments on the nomenclature and Z. Pouzar for reviewing the latin diagnosis.

\section{REFERENCES}

Ade A. 1935. Bemerkenswerte Pilze. Kryptog. Forschungen 2: 2327.

B a ral H. O. 1986. Beilage zum Beiheft 6. Z. Mykol., Typoskript., 19 pp.

Baral H. O. 1987. Der Apikalapparat der Helotiales. Eine lichtmikroskopische Studie über Arten mit Amyloidring. Z. Mykol. 53 (1): 119136.

B a ral H. O., Mars on G. 2005. In vivo veritas. Over 10.000 scans of fungi and plants, with materials on vital taxonomy and xerotolerance (DVD ROM).

Baral H. O., Krieglsteiner G. J. 1985. Bausteine zu einer Askomyzeten Flora der Bundesrepublik Deutschland: In Süddeutschland gefundene Inoperkulate Diskomyzeten mit taxonomischen, ökolo gischen, chorologischen Hinweisen und einer Farbtafel. Z. Mykol., Beiheft 6:1 160.

Breiten bach J., Kränzlin F. 1981. Pilze der Schweiz, Ascomyzeten. Luzern.

Cha mbers S. M., Willi a ms P. G., Se ppelt R. D., Ca irn ey J. W. G. 1999. Molecular identification of Hymenoscyphus sp. from rhizoids of the leafy liverwort Cephaloziella exiliflora in Australia and Antarctica. Mycol. Res. 103 (3): 286288.

Cle me nt s F. E. 1911. Nova fungorum Coloradensium genera. Minnesota Botanical Studies 4 (2): 185 188.

Dennis R. W. G. 1956. A revision of the British Helotiaceae in the herbarium of the Royal Botanic Garden, with notes on related European species. Mycol. Pap. 62: 1216.

Den n is R. W. G. 1964. Remarks on the genus Hymenoscyphus, with observation on sundry species re ferred by Saccardo and others to the genus Helotium, Pezizella or Phialea. Persoonia 3: 2980.

De $\mathrm{n} n$ is R. W. G. 1971. New or interesting British microfungi. Kew Bull. 25: 335374.

Garcia G., Van Vooren V. 2005. Un discomycète inoperculé plutôt discret, Pezoloma ciliifrea, et remarques sur le genre Pezoloma. Bull. mens. Soc. linn. Lyon 74, num. spécial, p. 115129.

Grelet L. J. 1948. Les Discomycètes de France 18. Rev. Myc. (Paris) N. S. 13: 105134.

Ha mblet on S., Huhtinen S., Curra h R.S. 1999. Hymenoscyphus ericae: a new record from western Canada. Mycol. Res. 103: 13911397.

Höhnel F.V. 1926. Über die Gattung Pezizella Fuckel. 2. Mitteilung. Mitt. Bot. Lab. Techn. Hochsch. Wien 3: 94108. 
Künkele U., Lohmeyer T. R., Baral H. O. 2005. Stamnaria americana, ein in Auwäldern vermut lich häufiger, aber aus Deutschland bisher nicht berichteter Parasit an Equisetum hyemale. Mycol. Bav. 7: 320 .

Lizoň P. 1992. The genus Hymenoscyphus (Helotiales) in Slovakia, Czechoslovakia. Mycotaxon 45: 159.

Nannfeldt A. 1932. Studien über die Morphologie und Systematik der nicht lichenisierten inoperculaten Discomyzeten. Nova Acta Regiae Soc. Scient. Upsal., Ser. 4, 8: 1368.

Pöde r R., Sche u e r C. 1994. Moserella radicicola gen. et sp. nov., a new hypogeous species of Leotiales on ectomycorrhizas of Picea abies. Mycol. Res. 98 (11): 13341338.

Svrček M. 1959. New ascomycetes for Čzechoslovakia (in Čzech). Česka Mykol. 13: 124125.

Triebel D., Baral H. O. 1996. Notes on the ascus types in Crocicreas with a characterization of se lected taxa. Sendtnera 3: 199218.

Triebel D., B a ral H. O. 1999. Microfungi exsiccati fasc. 1518.

Verkley G. J. M. 1995. The ascus apical apparatus in Leotiales: an evaluation of ultrastructural char acters as phylogenetic markers in the families Sclerotiniaceae, Leotiaceae, and Geoglossaceae. Proef schrift, Leiden, 209 pp.

White W. L. 1942. Studies in the genus Helotium I. A review of the species described byPeck. Mycologia 34: 154179.

Zhang Y. H., Zhu ang W. Y. 2004. Phylogenetic relationships of some members in the genus Hymeno scyphus (Ascomycetes, Helotiales). Nova Hedwigia 78: 475484.

\section{Hymenoscyphus subcarneus, mało znany miseczniak występujący na mszakach, zebrany w Białowieskim Parku Narodowym}

\section{Streszczenie}

Hymenoscyphus subcarneus został zebrany jako pasożytujący na wątrobowcu Cephalozia catenulata w Białowieskim Parku Narodowym; został opisany i zilustrowany na podstawie świeżych okazów. Dwie, nieznane dotychczas cechy zostały opisane: worki z pierścieniem api kalnym typu Calycina oraz charakterystyczna zawartość żywych parafiz.

Ponadto studiowano również zielnikowe okazy Pohlia gracilis z Grimsel w Szwajcarii, na których odkryto nowy rodzaj Roseodiscus.

Autorzy dyskutują wzajemne relacje i taksonomię tego grzyba z podobnymi gatunkami występującymi na pędach skrzypów Hymenoscyphus rhodoleucus i H. equisetinus. Rozpatry wane są też podobieństwa i różnice między Roseodiscus a bliskimi rodzajami jak Calycina, Stamnaria, Rhizoscyphus i Pezoloma. 
